Jurnal Health Sains: p-ISSN: 2723-4339 e-ISSN: 2548-1398

Vol. 2, No. 5, Mei 2021

\title{
EFEKTIVITAS LATIHAN RELAKSASI OTOT PERNAFASAN TERHADAP PENURUNAN NYERI PADA PASIEN PASCA CATETERISASI JANTUNG
}

\author{
Uun Nurulhuda dan Elya Netty \\ Politeknik Kesehatan Kemenkes Jakarta, Indonesia \\ Email: uun_kmb2006@yahoo.com dan nettyelya@yahoo.com
}

\begin{tabular}{l}
\hline ARTIKEL INFO \\
\hline Tanggal diterima: 5 Mei 2021 \\
Tanggal revisi: 15 Mei 2021 \\
Tanggal yang disetujui: 25 Mei \\
2021 \\
\hline
\end{tabular}

Keywords:

cardiac catheterization; pain

\begin{abstract}
Cardiac catheterization is a mandatory procedure that is performed before heart surgery and has the highest level of accuracy (96\% -99\%) to detect abnormalities in the heart, especially coronary heart disease. Through relaxation exercises the nurse's respiratory muscles help patients achieve stable hemodynamics and prevent respiratory complications due to pain after cardiac catheterization. This study aims to identify the effectiveness of breathing muscle relaxation exercises on pain reduction in patients after cardiac catheterization. The design of this study was a quasiexperimental study with a pre-post test approach, which was conducted in May-July 2018. The research subjects used inclusion criteria, namely patients undergoing cardiac catheterization at the public hospital in the rebo market area. Measuring instruments in data collection use a structured format. Breathing muscle relaxation exercises are the variables in this study, while the dependent variable is the level of pain after cardiac catheterization. The results of the independent $T$ test and paired $T$ test and the general linear model repeated measures prove the existence of a significant difference in the level of pain between before and after the relaxation exercises of respiratory muscles $(P=0.000)$. The average level of pain in the intervention group before the deep breathing relaxation exercise was 3.9, while the average level of pain after the deep breathing relaxation exercise decreased to 2.7. While the average level of pain in the control group with a standard given from the hospital that is distraction is 2.6, while the average level of pain after exercise decreased to 1.6.
\end{abstract}

\begin{abstract}
ABSTRAK
Katerisasi jantung merupakan prosedur wajib yang dilakukan sebelum operasi jantung dan memiliki tingkat ketepatan paling tinggi (96\%-99\%) untuk mendeteksi penyakit jantung koroner. Melalui latihan relaksasi otot pernapasan sangat membantu pasien mencapai hemodinamik yang stabil dan mencegah komplikasi pernapasan akibat nyeri pasca kateterisasi jantung. Penelitian ini bertujuan untuk mengidentifikasi efektifitas latihan relaksasi otot pernapasan terhadap penurunan nyeri pada pasien pasca kateterisasi jantung. Desain penelitian ini kuasi eksperimen dengan
\end{abstract}

$\begin{array}{ll}\text { How to } & \text { Nurulhuda Uun dan Elya Netty (2021) Efektivitas Latihan Relaksasi Otot Pernafasan terhadap Penurunan Nyeri Pada } \\ \text { cite: } & \text { Pasien Pasca Cateterisasi Jantung. Jurnal Health Sains 2(5). https://doi.org/10.46799/jhs.v2i5.172 } \\ \text { E-ISSN: } & 2723-6927 \\ \text { Publishe } & \text { Ridwan Institute } \\ \text { d by: } & \end{array}$


pendekatan pre-post test, dilakukan pada bulan Mei-Juli 2018. Subyek penelitian menggunakan kriteria inklusi yaitu pasien yang dilakukan kateterisasi jantung. Alat ukur dalam pengumpulan data menggunakan format terstruktur. Latihan relaksasi otot pernapasan merupakan variabel dalam penelitian, sedangkan yang menjadi variabel terikatnya adalah tingkat nyeri pasca kateterisasi jantung. Hasil uji independent $\mathrm{T}$ test dan paired $\mathrm{T}$ test serta uji general linier model repeated measures membuktikan adanya perbedaan tingkat nyeri bermakna antara sebelum dan sesudah latihan relaksasi otot pernapasan $(\mathrm{P}=0.000)$. Rata-rata tingkat nyeri pada kelompok intervensi sebelum dilakukan latihan relaksasi napas dalam adalah 3.9, sedangkan rata-rata tingkat nyeri sesudah dilakukan latihan relaksasi napas dalam menurun menjadi 2.7. Sedangkan rata-rata tingkat nyeri pada

Kata Kunci:

kateterisasi jantung; nyeri kelompok kontrol dengan standar yang diberikan dari rumah sakit yaitu distraksi adalah 2.6, sedangkan rata-rata tingkat nyeri sesudah dilakukan latihan menurun menjadi 1.6.

\section{Pendahuluan}

Fungsi jantung sangat vital bagi kehidupan seseorang dengan memompa dan mengatur kelancaran sirkulasi darah melalui pembuluh darah yang terdapat pada seluruh tubuh, sehingga bagian-bagian tubuh tersebut dapat menjalankan fungsinya dengan baik. Jantung bekerja secara terus menerus tanpa perintah dari otak dan digerakkan oleh otot motorik (Purnomo, 2014).

Pada era globalisasi sekarang ini terjadi perubahan gaya hidup seiring dengan pertumbuhan ekonomi, sosial budaya dan teknologi yang memengaruhi perubahan fungsi vital jantung (Jun, 2014). Gaya hidup yang tidak sehat seperti perilaku merokok, kurangnya aktivitas fisik, diit kurang serat serta tekanan lingkungan kerja yang menyebabkan stres berkepanjangan meningkatkan risiko terjadinya penyakit kardiovaskuler seperti penyakit jantung koroner. Penyakit jantung koroner atau penyakit arteri koroner (Coronary Artery Disease) sering dikaitkan dengan terjadinya pengerasan pada pembuluh darah arteri. Pembuluh darah arteri mengalami penurunan elastisitas yang disebabkan oleh penumpukan plak dalam pembuluh darah, sehingga arteri menjadi tersumbat karena tertutup oleh material plak. Penyumbatan pembuluh darah menyebabkan arteri yang mensuplai darah ke otot jantung (arteri koroner) mengalami gangguan yang mengakibatkan terjadinya iskemik dan nekrosis pada jantung (Workman \& Ignatavicius, 2006).

Menurut (Hawk, 2012) beberapa faktor risiko terjadinya penyakit jantung koroner terdiri dari faktor risiko yang tidak dapat diubah dan faktor risiko yang dapat diubah. Faktor risiko yang tidak dapat diubah meliputi keturunan, ras, usia dan jenis kelamin. Sedangkan faktor risiko yang dapat diubah meliputi merokok, hipertensi, peningkatan serum kolesterol, diabetes mellitus, kurangnya aktivitas fisik dan obesitas

Penyakit kardiovaskuler merupakan penyakit penyebab kematian utama di dunia. Penyakit ini menyerang penduduk baik dinegara maju maupun negara berkembang (Supriyono, 2008). Penyakit ini umumnya mengenai orang dewasa dan orang tua, namun hal yang mengkhawatirkan adalah kecenderungan terdapat juga pada orangorang usia muda. Di dunia terdapat 1.000.000.000 orang dewasa menderita penyakit kardiovaskuler dan menurut laporan World Health Organization (WHO) tahun 
2012 menunjukkan 17,5 juta orang di dunia meninggal akibat penyakit kardiovaskuler atau $31 \%$ dari 56,5 juta kematian di seluruh dunia. Lebih dari $3 / 4$ kematian akibat penyakit kardiovaskuler (www.depkes.go.id/article/view, diperoleh tanggal 25 Mei 2018).

Di Indonesia penyakit jantung dan pembuluh darah sejak tahun 1995 telah dinyatakan sebagai penyebab kematian utama, yang perkembangannya terus meningkat. Berdasarkan data Survei Sample Regristration System (SRS) pada 2014 di Indonesia menunjukkan, Penyakit Jantung Koroner (PJK) menjadi penyebab kematian tertinggi pada semua usia setelah stroke, yakni sebesar 12,9\% (Kemenkes, 2018).

Deteksi plak aterosklerosis dengan angiografi koroner merupakan "gold standard" pada penyakit jantung koroner (Grossman, 2000). Kateterisasi jantung memiliki tingkat ketepatan paling tinggi (96\%-99\%) untuk mendeteksi adanya kelainan pada jantung terutama penyakit jantung koroner (Sari et al., 2017). Proses kateterisasi jantung akan memberi informasi tentang seberapa baik fungsi jantung, mengidentifikasi masalah dan memungkinkan untuk dilakukan pembukaan arteri yang tersumbat.

Proses kateterisasi jantung menjadi wajib dilakukan sebelum melakukan operasi jantung pasang ring ataupun operasi jantung bypass, karenan tindakan memberi informasi tentang seberapa baik fungsi jantung, mengidentifikasi masalah dan memungkinkan untuk dilakukan pembukaan arteri yang tersumbat. Kateterisasi jantung sebagai bagian dari pemeriksaan penyakit jantung, dapat menentukan lokasi penyempitan atau penyumbatan pada pembuluh darah yang dapat menyebabkan keluhan nyeri dada (angiogram), mengetahui jumlah oksigen di dalam jantung anda (penilaian hemodinamik), memeriksa tekanan di dalam jantung, mengambil sampel jaringan dari jantung (biopsy) dan dapat mendiagnosis adanya kelainan/defek jantung yang ada sejak lahir (kelainan jantung bawaan) (Supriyono, 2008).

\section{Metode Penelitian}

Desain penelitian yang digunakan adalah quasi experiment dengan pendekatan control group pre-test post-test. Pada desain ini terdapat 2 kelompok, yaitu kelompok intervensi dan kelompok kontrol. Kelompok intervensi diberi perlakuan standar rumah sakit ditambah latihan relaksasi otot pernapasan dari peneliti, sedangkan kelompok kontrol (control group) tidak mendapat perlakuan dari peneliti tetapi hanya mendapat perlakuan standar rumah sakit. Pengambilan data dilakukan pada kedua kelompok dan akibat yang diperoleh dari perlakuan dapat diketahui pasti karena dibandingkan dengan yang tidak mendapat perlakuan dari peneliti. Peneliti melihat perbedaan pencapaian antara kelompok intervensi (O4-O1) dengan pencapaian kelompok kontrol (O8-O5) (Arikunto, 2019).

Populasi dalam penelitian ini adalah semua pasien pasca Kateterisasi Jantung yang dirawat di rumah sakit. Pengambilan Sampel penelitian dilakukan menggunakan non probability sampling jenis consecutive sampling, yaitu cara pengambilan sampel yang dilakukan dengan memilih sampel yang memenuhi kriteria penelitian sampai kurun waktu tertentu sehingga jumlah sampel yang diperlukan terpenuhi (Marlina \& Widjaja, 2012). Pemilihan sampel tidak memungkinkan untuk menggunakan sistem randomisasi untuk mengelompokkan responden kedalam kelompok intervensi dan kelompok kontrol. Pada penelitian ini didapatkan 30 sempel perlakuan dan 30 sampel control yang memenuhi kriteria inklusi responden sehingga jumlah sampel sudah memenuhi besar minimal sampel. Besar sampel tersebut sudah sesuai dengan 
aturan besar sampel minimal oleh (Doyle et al., 2002).

\section{Hasil dan Pembahasan}

\section{A. Hasil Penelitian}

Pada bab ini peneliti akan menyajikan dan menjelaskan tentang hasil penelitian. Penyajian dan penjelasan tersebut meliputi gambaran karakteristik responden yang terdiri dari gambaran usia, jenis kelamin, budaya, tingkat nyeri baik pada kelompok intervensi maupun pada kelompok kontrol. Selain itu peneliti menyajikan tentang hasil analisis bivariat dengan uji statistik korelasi, independent $t$ test, partial $t$ test, dan anova serta uji generallinier model repeated measures.

Pada penelitian ini kelompok intervensi adalah kelompok pasca cateterisasi jantung yang diberikan intervensi latihan relaksasi napas dalam, sedangkan kelompok kontrol adalah kelompok pasien pasca cateterisasi jantung yang mendapat penatalakasanaan sesuai tindakan rumah sakit.

\section{Analisis Univariat Gambaran \\ Karakteristik Responden}

Analisis univariat berikut ini menggambarkan distribusi frekuensi dari seluruh variabel yang meliputi karakteristik responden (Usia, Jenis Kelamin, Tingkat Nyeri) pada pasien pasca kateterisasi jantung dengan uraian sebagai berikut:

a. Usia

Karakteristik usia responden berdasarkan hasil analisis univariat dapat dilihat pada tabel 1 dibawah ini.

\section{Tabel 1}

\section{Distribusi Rata-rata Usia Responden Di RSUD Pasar Rebo Jakarta,} Oktober-Nopember $2018(n=30)$

\begin{tabular}{|c|c|c|c|c|c|c|c|}
\hline Variabel & Mean & Median & SD & $\begin{array}{c}\text { Min } \\
- \\
\text { Max } \\
\end{array}$ & $\mathbf{N}$ & $\begin{array}{c}95 \% \\
\text { CI }\end{array}$ & $\begin{array}{c}\mathbf{P} \\
\text { Value }\end{array}$ \\
\hline $\begin{array}{c}\text { Usia } \\
\begin{array}{c}\text { Kel. } \\
\text { Intervens }\end{array}\end{array}$ & 57.93 & 58 & 9.07 & $\begin{array}{l}38- \\
73\end{array}$ & 30 & 54.5 & \\
\hline
\end{tabular}

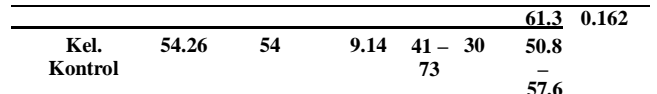

Rata-rata usia responden pada kelompok intervensi adalah 57.93 tahun $(\mathrm{SD}=9.07)$ dengan median 58 tahun. Usia termuda 38 tahun dan tertua 73 tahun. Sedangkan rata-rata usia responden pada kelompok kontrol adalah 54.26 tahun $(\mathrm{SD}=9.14)$ dengan median 54 tahun. Usia termuda 41 tahun dan tertua 73 tahun. Dari hasi estimasi dapat disimpulkan bahwa $95 \%$ diyakini rata-rata usia responden kelompok intervensi adalah diantara 54.5 tahun sampai dengan 61.3 tahun, sedangkan pada kelompok kontrol adalah 50.8 tahun sampai dengan 57.6 tahun. Hasil analisis lebih lanjut didapatkan ada perbedaan yang bermakna antara usia kelompok intervensi dengan kelompok kontrol ( $\mathrm{P}$ $=0.162$ ).

b. Jenis Kelamin

Karakteritik menurut jenis kelamin responden dapat dilihat pada tabel 2 dibawah ini:

\section{Tabel 2}

Distribusi Responden Menurut Jenis Kelamin Di RSUD Pasar Rebo Jakarta, Oktober-Nopember $2018(n=30)$

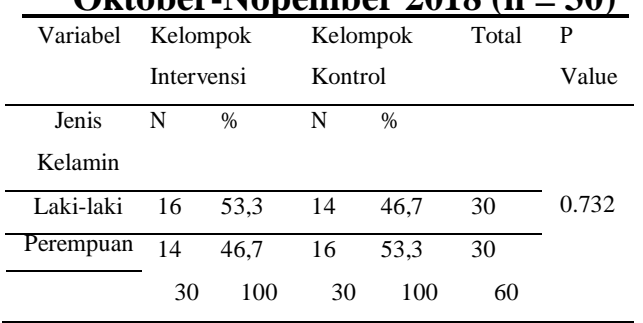

Hasil analisi menunjukkan distribusi jenis kelamin pada kedua kelompok hampir merata. Jenis kelamin laki-laki pada kelompok intervensi adalah 16 orang $(53,3 \%)$, dan perempuan sebanyak 14 orang (46.7\%), sedangkan pada kelompok 
kontrol adalah 14 orang $(46.7 \%)$, dan perempuan sebanyak 16 orang $(53.3 \%)$. Hasil analisis lebih lanjut didapatkan tidak ada perbedaan yang bermakna antara jenis kelamin kelompok intervensi dengan kelompok kontrol $(\mathrm{P}=0.732)$.

c. Karakteristik responden menurut latar belakang budaya dapat dilihat pada tabel 3 dibawah ini :

Tabel 3

Distribusi Responden Menurut

Latar Belakang Di RSUD Pasar

Rebo Jakarta, Oktober-November

\begin{tabular}{lllllll}
\multicolumn{8}{c}{$\mathbf{2 0 1 8}(\mathbf{n = 3 0})$} & & \\
\hline Variabe & $\begin{array}{l}\text { Kelompok } \\
\text { Intervensi }\end{array}$ & \multicolumn{2}{l}{ Kelompok } \\
& Kontrol & & Total & P \\
& $\mathrm{N}$ & $\%$ & $\mathrm{~N}$ & $\%$ & & Value \\
\hline Budaya & & & & & & \\
& & & & & & \\
\hline Betawi & 4 & 13,3 & 4 & 13,34 & 8 & \\
\hline Jawa & 26 & 86,7 & 26 & 86,267 & 52 & \\
\hline & 30 & 100 & 30 & 100 & 60 & \\
\hline
\end{tabular}

Distribusi latar belakang budaya responden menunjukkan distribusi yang sama pada kedua kelompok. Pada kelompok intervensi responden dengan latar belakang Betawi terdapat 4 orang $(13.3 \%)$ dan Jawa 26 orang $(86,7 \%)$. Begitu juga dengan kelompok kontrol sama dengan kelompok intervensi dengan latar belakang Betawi terdapat 4 orang (13.3\%) dan Jawa 26 orang $(86,7 \%)$.

\section{B. Pembahasan}

Hasil penelitian ini sesuai dengan teori yang menyebutkan bahwa usia merupakan faktor risiko terjadinya penyakit jantung koroner. Gejala dari penyakit jantung koroner sebagian besar muncul pada usia diatas 40 tahun. Hasil penelitian ini juga mendukung yang menyatakan bahwa usia mempunyai pengaruh yang bermakna terhadap penyakit jantung coroner.

a. Usia

Usia merupakan salah satu faktor risiko terjadinya penyakit jantung koroner yang tidak dapat diubah. Peningkatan usia mempengaruhi terjadinya risiko maupun keparahan penyakit jantung koroner. Perubahan fisik yang berhubungan dengan usia meliputi perubahan otot jantung menjadi kurang elastis dan kurang efektif untuk memompa darah, selain itu juga terjadi perubahan pada sistem konduksi jantung dan penurunan elastisitas arteri akibat penumpukan plak pada dinding pembuluh darah. (Hawk, 2002) Disamping faktor usia, penyakit jantung koroner pada responden dapat dipengaruhi oleh kebiasaan merokok, makanan tinggi kolesterol, kurang aktifitas serta penyakit diabetes mellitus (Wilson, 2014).

Hasil analisis dengan uji korelasi menunjukkan bahwa tidak ada perbedaan yang bermakna antara umur dengan tingkat nyeri $(\mathrm{p}=0.38)$, dari hasil penelitian ini tidak mendukung teori bahwa usia dan perbedaan perkembangan diantara kelompok usia mempengaruhi seseorang bereaksi terhadap nyeri (Potter, 2010). Usia dewasa dapat mengartikan nyeri sebagai kelemahan, kegagalan dan kehilangan kontrol sehingga mereka sering tidak melaporkan rasa sakit yang dialami, sedangkan penurunan fungsi neuromuskuler pada lanjut usia menghambat mereka untuk mengekspresikan rasa nyeri, Transmisi dan persepsi nyeri dapat diperlambat dengan proses menua (Hawk, 2012).

b. Jenis Kelamin 
Hasil analisis ini jenis kelamin antara kelompok intervensi dan kelompok kontrol tidak sama. Hasil penelitian didapatkan jumlah responden jenis kelamin pada kedua kelompok hampir merata. Jenis kelamin laki-laki pada kelompok intervensi adalah 16 orang, dan perempuan sebanyak 14 orang, sedangkan pada kelompok kontrol adalah 14 orang, dan perempuan sebanyak 16 orang. Hasil analisis lebih lanjut didapatkan tidak ada perbedaan yang bermakna antara jenis kelamin kelompok intervensi dengan kelompok kontrol $(\mathrm{P}=0.732)$. Menurut Asosiasi Jantung Amerika (AHA), lebih dari 1 pada 3 pria dewasa mengidap penyakit jantung, dan lebih dari $48 \%$ pria meninggal karena kondisi jantung dan pria berisiko tinggi terkena penyakit jantung. Lebih dari $60 \%$ pria di Indonesia merokok, yang dapat menyebabkan penyempitan pembuluh darah, yang muncul sebagai pertanda awal jenis penyakit jantung tertentu. https://hellosehat.com

Hasil penelitian ini mendukung data Centers for Disease Control dan Prevention (CDC), menyatakan bahwa wanita ternyata lebih sedikit berisiko terkena penyakit jantung koroner sampai berumur 55 tahun dibandingkan dengan pria yang dapat terkena serangan jantung di usia yang lebih muda. Pada rentang usia 25-35 tahun, angka kejadian penyakit jantung koroner pada pria dibandingkan wanita sebesar 3:1. Wanita baru akan mengalami kenaikan risiko penyakit jantung saat memasuki usia menopause. Sementara itu pada pria, risiko penyakit ini bisa muncul sejak berusia 20-an tahun. https://hellosehat.com/pusatkesehatan/s erangan-jantung dan factor kebiasaan merokok menjadi habit dimana merokok dapat merangsang proses aterosklerosis karena efek langsung terhadap dinding arteri. Karbon monoksida yang dapat menyebabkan hipoksia jaringan arteri dan nikotin menyebabkan mobilisasi katekolamin, sehingga merangsang kenaikan tekanan darah dan menyebabkan kerusakan endotel arteri.Pada hasil penelitian ini, walaupun tingkat nyeri wanita lebih tinggi dibandingkan dengan laki-laki, namun perbedaan tersebut tidak bermakna. Hal ini mungkin disebabkan jumlah sampel yang tidak seimbang antara laki-laki dan wanita, laki-laki berjumlah 28 orang dan wanita hanya 2 orang.

c. Latar Belakang Budaya Responden Karakteristik responden menurut latar belakang budaya pada kedua kelompok penelitian ini tidak ada perbedaan. Pada kelompok intervensi responden dengan latar belakang Betawi terdapat 4 orang (13.3\%) dan Jawa 26 orang $(86,7 \%)$. Begitu juga dengan kelompok kontrol sama dengan kelompok intervensi dengan latar belakang Betawi terdapat 4 orang (13.3\%) dan Jawa 26 orang (86,7\%). Pada penelitian ini didapatkan responden yang tidak terlalu bervariasi, hasil penelitian ini tidak sesuai dengan teori yang menyatakan bahwa setiap orang dengan budaya yang berbeda akan mengatasi nyeri dengan cara yang berbeda-beda. Orang yang mengalami intensitas nyeri yang sama mungkin tidak melaporkan atau berespon terhadap nyeri dengan cara yang sama. Ada perbedaan makna dan sikap yang dikaitkan dengan nyeri pada berbagai budaya. Budaya mempengaruhi seseorang bagaimana cara toleransi terhadap nyeri, mengintepretasikan nyeri, dan bereaksi secara verbal atau 
non-verbal terhadap nyeri (LeMone, 2008).

Hasil penelitian tersebut berbeda dengan teori yang ada bahwa ras, budaya dan etnik merupakan faktor penting di dalam seseorang berespon terhadap nyeri. Individu akan mempersepsikan nyeri dengan cara yang berbeda yang juga berhubungan dengan budaya dan makna nyeri, adanya perbedaan hasil penelitian dengan teori antara lain faktor-faktor tersebut mempengaruhi semua respon sensori, termasuk respon terhadap nyeri (Hawk, 2012).

\section{Kesimpulan}

Pada era globalisasi sekarang terjadi perubahan gaya hidup seiring dengan pertumbuhan ekonomi, sosial budaya dan teknologi yang mempengaruhi perubahan fungsi vital jantung. Gaya hidup yang tidak sehat seperti perilaku merokok, kurangnya aktifitas fisik, diit kurang serat serta tekanan lingkungan kerja yang menyebabkan stres berkepanjangan meningkatkan risiko terjadinya penyakit kardiovaskuler seperti penyakit jantung koroner.

Beberapa faktor risiko terjadinya penyakit jantung koroner terdiri dari faktor risiko yang tidak dapat diubah dan faktor risiko yang dapat diubah. Faktor risiko yang tidak dapat diubah meliputi keturunan, ras, usia dan jenis kelamin. Sedangkan faktor risiko yang dapat diubah meliputi merokok, hipertensi, peningkatan serum kolesterol, diabetes mellitus, kurangnya aktifitas fisik dan obesitas. Metode penelitian ini meliputi Desain penelitian, sampel, tempat penelitian, waktu penelitian, alat pengumpulan data, Prosedur pengumpulan data, pengelolaan dan analisis data.

Hasil penelitian ini meliputi penyajian dan penjelasan tentang gambaran karakteristik responden yang terdiri dari gambaran usia, jenis kelamin, budaya, tingkat nyeri baik pada kelompok intervensi maupun pada kelompok kontrol. Selain itu peneliti menyajikan tentang hasil analisis bivariat dengan uji statistik korelasi, independent $t$ test, partial $t$ test, dan anova serta uji generallinier model repeated measures.

Penelitian ini dilaksanakan di RSUD Pasar Rebo dimulai pada Rabu kedua bulan Mei sampai Rabu keempat bulan Juli 2018. Sasaran pada penelitian ini adalah semua pasien pasca Kateterisasi Jantung yang dirawat di Rumah Sakit.

Rata-rata usia responden pada kelompok intervensi adalah 57.93 tahun dan rata-rata usia responden pada kelompok kontrol adalah 54.26 tahun. Hasil penelitian ini juga mendukung yang menyatakan bahwa usia mempunyai pengaruh yang bermakna terhadap penyakit jantung coroner.

Jenis kelamin laki-laki pada kelompok intervensi adalah 16 orang dan perempuan sebanyak 14 orang, sedangkan pada kelompok kontrol adalah 14 orang, dan perempuan sebanyak 16 orang. Pada hasil penelitian ini, walaupun tingkat nyeri wanita lebih tinggi dibandingkan dengan laki-laki, namun perbedaan tersebut tidak bermakna. Hal ini mungkin disebabkan jumlah sampel yang tidak seimbang antara laki-laki dan wanita, laki-laki berjumlah 28 orang dan wanita hanya 2 orang

Distribusi latar belakang budaya responden menunjukkan distribusi yang sama pada kedua kelompok.

Hasil penelitian ini menunjukkan bahwa Area Insersi responden pada kelompok intervensi paling banyak menggunakan arteri Radialis sebanyak 18 responden.

Dari hasil uji analisis bivariat lebih lanjut disimpulkan terdapat hubungan yang signifikan antara usia dengan selisih tingkat nyeri $(\mathrm{P}=0.184)$. Tidak ada perbedaan bermakna antara rata-rata selisih tingkat nyeri laki-laki dengan tingkat nyeri perempuan $(\mathrm{P}=$ 
0.357). Tidak ada perbedaan yang bermakna antara selisih tingkat nyeri masing-masing latar belakang budaya $(P=0.709)$. Dan tidak ada perbedaan yang bermakna antara rata-rata selisih tingkat nyeri responden yang menggunakan graft. $(\mathrm{P}=0.858)$.

\section{BIBLIOGRAFI}

Arikunto, S. (2019). Prosedur Penelitian Suatu Pendekatan Praktik. Rineka Cipta. Google Scholar

Doyle, S. E., Vaidya, S. A., O'connell, R., Dadgostar, H., Dempsey, P. W., Wu, T.T., Rao, G., Sun, R., Haberland, M. E., \& Modlin, R. L. (2002). Irf3 Mediates A Tlr3/Tlr4-Specific Antiviral Gene Program. Immunity, 17(3), 251-263. Google Scholar

Grossman, M. (2000). The Human Capital Model. In Handbook Of Health Economics (Vol. 1, Pp. 347-408). Elsevier. Google Scholar

Hawk, B. (2012). Life Of Black Hawk. Courier Corporation. Google Scholar

Jun, C. (2014). Perubahan Gaya Hidup Anak Muda Di Surakarta Akibat Berkembangnya Mall. Tesis Program Studi Kajian Budaya Pascasarjana Universitas Sebelas Maret Surakarta. Uns (Sebelas Maret University). Google Scholar

Kemenkes, R. I. (2018). Hasil Utama Riskesdas 2018. In Online) Http://Www. Depkes. Go. Id/Resources/Download/InfoTerkini/Materi_Rakorpop_2018/Hasil\% 20riskesdas (Vol. 202018). Google Scholar

Lemone, P. (2008). Burke.(2008). Medical Surgical Nursing: Critical Thinking In Client Care. Pearson Prentice Hall: New
Jersey. Google Scholar

Marlina, L., \& Widjaja, J. (2012). Hubungan Pendidikan Formal, Pengetahuan Ibu Dan Sosial Ekonomi Terhadap Infeksi Soil Transmitted Helminths Pada Anak Sekolah Dasar Di Kecamatan Seluma Timur Kabupaten Seluma Bengkulu. Indonesian Journal Of Health Ecology, 11(1), 79753. Google Scholar

Potter, W. J. (2010). The State Of Media Literacy. Journal of Broadcasting \& Electronic Media, 54(4), 675-696. Google Scholar

Purnomo, N. T. (2014). Sport Massage Terhadap Respons Cardio Vascular. Journal Of Physical Education And Sports, 3(1). Google Scholar

Sari, E. A., Arifin, M. Z., \& Fatimah, S. (2017). Perbandingan Hematoma Pasca Kateterisasi Jantung Berdasarkan Penekanan Bantal Pasir Dan Cold Pack. Jurnal Pendidikan Keperawatan Indonesia, 3(2), 100-114. Google Scholar

Supriyono, M. (2008). Faktor-Faktor Risiko Yang Berpengaruh Terhadap Kejadian Penyakit Jantung Koroner Pada Kelompok Usia< 45 Tahun (Studi Kasus Di Rsup Dr. Kariadi Dan Rs Telogorejo Semarang). Program Pascasarjana Universitas Diponegoro. Google Scholar

Wilson, V. (2014). Research Methods: Triangulation. Evidence Based Library And Information Practice, 9(1), 74-75. Google Scholar

Workman, M. L., \& Ignatavicius, D. D. (2006). Medical-Surgical Nursing: Critical Thinking For Collaborative Care. Elsevier Saunders. Google Scholar

\section{Copyright holder:}

Uun Nurulhuda dan Elya Netty (2021) 
Efektivitas Latihan Relaksasi Otot Pernafasan terhadap Penurunan Nyeri Pada Pasien Pasca Cateterisasi Jantung

\section{First publication right:}

Jurnal Health Sains

This article is licensed under:

(cc) (i) 